\title{
Chapter 2 \\ Educational Situation of Portuguese Ciganos: Social Changes versus Social Continuities
}

\author{
Maria Manuela Mendes and Olga Magano
}

\begin{abstract}
The purpose of this chapter is to present and discuss the main impacts of Portuguese public policies in the area of education in Portugal, since 25 April 1974. To this end, diversified information was collected, processed and analysed involving legal and other documents about these national policies, especially those of greater impact on Ciganos, in addition to thorough mapping of ongoing projects of local and social support in the Lisbon and Porto metropolitan areas, where the empirical research is being carried out. At a later stage, interviews were held with technical staff, project coordinators and local institutions, as well as Ciganos and their families. The purpose of using various data collection techniques is to capture the reality experienced by Cigano individuals and families, namely patterns of continuity and social change, particularly in the area of education, through triangulation between the discourses of informants and scientific knowledge already consolidated in these matters. We present a critical and reflexive interpretation of the policy orientations and achieved social rights, focusing on narratives of Ciganos, stakeholders and school representatives centred on what has changed in the school trajectories of Ciganos, in terms of continuity, success and permanence in public education.
\end{abstract}

\footnotetext{
The open access publication of this chapter was funded by Portuguese National Funds through the Fundação para a Ciência e a Tecnologia, R\&D Unit UIDB/03126/2020.

The original version of this chapter was revised. A correction to this chapter can be found at https://doi.org/10.1007/978-3-030-52588-0_15.
}

\author{
M. M. Mendes (ه) \\ Faculty of Architecture, University of Lisbon, Lisbon, Portugal \\ University Institute of Lisbon (ISCTE-IUL), Centre for Research and Studies in Sociology \\ (CIES-IUL), Lisbon, Portugal \\ O. Magano \\ Universidade Aberta, Lisbon, Portugal \\ University Institute of Lisbon (ISCTE-IUL), Centre for Research and Studies in Sociology \\ (CIES-IUL), Lisbon, Portugal \\ e-mail: olga.magano@uab.pt
}


Keywords Ciganos/Roma $\cdot$ Public policies $\cdot$ Education $\cdot$ Families $\cdot$ Portugal

\section{Introduction}

In the first decade of this century the "Cigano/Roma issue' ${ }^{1}$ became a hot topic in European political debates. However, in Portugal, ${ }^{2}$ until recently, political and public discussions around this topic remained residual and at the margin of other European Member State efforts, pending between invisibility in society and public policies and stereotyped negative representations. Such negative imagery helps to explain why Ciganos are still the largest rejected minority in Portugal (Silva et al. 2008).

More recently, along with an intensification of the official discourse on the social integration of Ciganos/Roma people in Europe, the 'integration' of Portuguese Ciganos began to take on an unprecedented centrality in the national context, finally culminating in the establishment of a National Strategy for the integration of 'Comunidades Ciganas' ('Roma Communities') in 2013 (Resolution of the Council of Ministers No. 25/ 2013 of 27 March), this time following a direct request from the European Union to its Member States (European Parliament 2011).

As the production of ethnic-based statistics is explicitly prohibited by the Constitution of the Portuguese Republic, there are no quantitative and cross-sectional studies at a national level enabling us to know the situation and the access of Ciganos to education, housing, employment, health, justice and social security, or to evaluate the implementation of the social policies associated to these aspects.

Accordingly, this chapter aims to critically analyse the changes and continuities that have recently taken place as well as during the last ten years in Portugal in terms of success and continuity of schooling of Ciganos, men and women. Presently, Cigano men and women still do not complete the 12 years of compulsory education (being very far from this goal) or acquire the necessary skills to integrate into the labour market (Mendes et al. 2014). Based on a literature review about policies, programmes and projects active in the last decade, which evidence suggests has influenced an increase of the Ciganos' educational qualifications in Portugal, and on recent research findings obtained from a 2-year research project conducted by the authors in the Lisbon and Porto metropolitan areas, which involved fieldwork conducted in neighbourhoods marked by a high concentration of Portuguese Cigano families, inside urban areas, school ethnographies and in-depth interviews with Ciganos and individual and institutional stakeholders who worked in the territories where Cigano families and persons lived, this article aims to critically analyse the persistence of social regularities in associating Portuguese Ciganos to low education qualifications and the persistence of high school absenteeism and dropout rates. The Portuguese case is also contextualised within a wider European education policy targeting Ciganos. In view of the striking absence of research on the impact of

\footnotetext{
${ }^{1}$ We maintain the term in Portuguese, as it is still recognized and used by the Portuguese Ciganos themselves. In international context, the term can be understood as Portuguese Roma or Romani persons. ${ }^{2}$ Portugal lived a democratic revolution on 25 April 1974.
} 
academic success and school continuity on Cigano students, both at the individual and family/community levels (Bereményi and Carrasco 2015, p. 7) this reflection hopes to mitigate this lacuna which is transversal to the Portuguese scenario.

Although Cigano children and youth are more present at Portuguese public schools compared to previous periods, there continues to be a high number of cases of educational underachievement and early school leaving. These circumstances reveal the incapacity of policies and even compensatory measures to overcome the challenge of (in)completion of compulsory education, a situation that persists and continues largely unresolved in Portuguese society in relation to Cigano citizens.

It is in this analytical context that the present chapter is founded on the results of qualitative research which demonstrates minor changes in Cigano-school relations. It is also clear that there is a tendency towards the persistent and continuous reproduction of social and educational inequalities in relation to the Ciganos. This analysis begins by outlining an updated diagnosis of the educational situation of the Ciganos in Portugal. We subsequently examine the projects and policies of greatest impact on Cigano schooling, attempting to draw out what has changed in the relationship between families and school; and lastly, some concluding notes are presented concerning school-family articulation in the Cigano community.

\section{Background and the Portuguese Context}

In Portugal, estimates suggest that there are about 40,000 to 60,000 Portuguese Cigano citizens (ACIDI 2013) and although these numbers vary according to the sources and the theoretical and methodological procedures used, it is consensual that it is a small population number compared to other European countries. Nevertheless, the living conditions and challenges experienced by Portuguese Ciganos are close to those of other countries, particularly in terms of the analytical axes often referred to: education, employment and vocational training, housing, health, but also in terms of the discrimination to which they are subject and the ignorance about their plural ways of life (ERRC/NUMENA 2007; FRA 2012). Ciganos are affected by social and economic vulnerability, reflecting a complex set of interrelated factors. According to O'Hanlon (2010) "Access to education and the educational attainment of Gypsy/Travellers is affected by direct and systemic discrimination in, and exclusion from, education and influenced by their overall conditions of life, which are invariably characterised by high unemployment, substandard housing and poor access to health services, creating a vicious circle of poverty, exclusion and marginalisation" (p. 250).

The wave of scientific analysis produced from the 1990s up to the present prevailing qualitative and micro studies located in very specific geographic areas has contributed to a better understanding of Portuguese citizens who identify themselves as Ciganos (Mendes and Magano 2013). These studies evince the plurality of ways of living, the exclusions and tensions experienced, the complexity 
of intra and inter-ethnic relations (Afonso 2012; Mendes and Magano 2013), and also the changes and continuities between generations and those who are considered by other Ciganos as living a life as 'Senhores' ('Gentlemen') (Magano 2014). The national study (Mendes et al. 2014) corroborates most of the findings already demonstrated by previous research but has also exposed the harsh reality still experienced by Ciganos and the deep inequalities between Portuguese Ciganos and non-Ciganos. The data collected show the existence of strong contrasts at the level of school education between Ciganos and non-Ciganos and between Cigano men and women. Thus, among the 1599 respondents, about $1 / 3$ of them did not go beyond primary education or never attended school and only $2.8 \%$ finished secondary and higher education (Mendes et al. 2014). In the European context, school segregation and other forms of discrimination are also common. There are exclusion dynamics from the moment Ciganos enter school: classification procedures are generated and Ciganos are moved to special education (for disabilities) and they show a minor presence in higher education (IRS 2008). This is a very serious form of discrimination and violation of the Rights of Children and Youth.

The characterisation achieved somewhat reinforces several of the stereotypes often used towards Ciganos, especially when viewed in a linear and deterministic manner: the prevalence of low schooling levels and high absenteeism rates (starting in primary education), high school dropout in the fifth and sixth year of education, particularly for girls, evidence of strong gender inequalities and a high dependence on social policy measures, namely, Social Integration Income ('RSI') and other family allowances. Despite this, there has been a significant increase in school attendance since 2000. Nevertheless, the results of our study show important ongoing changes and their impacts on various dimensions of Cigano life in Portugal, such as a growing interest in schooling, an improvement of the relationship between the school and the families, a reduction of absenteeism and school dropout rates through RSI policy and a higher presence at nurseries and kindergartens. Furthermore, it is important to mention the increasing participation of women in literacy courses (Mendes et al. 2014). The increase of educational qualifications is related to trajectories of social mobility in Portuguese society (Almeida et al. 1993) and it is known that socialisation through schooling promotes the learning of citizenship rights (Vala et al. 1999). Yet, in the European sphere, Ciganos are often perceived as the most disadvantaged minority in Europe. However, it should be mentioned that the Ciganos are not the only ethnic minority that experiences educational deprivation, such as is the case of Afro-descendants in Portugal (Seabra et al. 2016). People from ethnic and language minorities all over the world face similar disadvantages (for an overview, see UNESCO 2010, pp. 149-153). Even though the patterns of educational exclusion of different ethnic minorities vary, the structural drivers underlying these processes, might be similar for such heterogeneous groups as migrants, indigenous people and Gypsies/Roma (Brüggemann 2012, pp. 10-11). 


\section{What Do we Know About the Educational Situation of Portuguese Ciganos?}

According to the European Union Agency for Fundamental Rights (FRA 2017), World Bank (Gatti et al. 2016) and other international bodies, Roma people and families are severely affected by social and economic vulnerability, arising from a complex interplay of factors of multiple, historical, structural and intersectional discrimination, which are correlated with each other. Gender, as well as other characteristics such as age, religion, nationality and socioeconomic status, cross with the Roma ethnicity generating a bundle of variables that intensify the complexity of the situations of inequality marking the lives of these citizens. The findings of EU-MIDIS II (FRA 2016) show that Roma children fall short of their non-Roma classmates in all education indicators. Merely half (53\%) of Roma children aged from four to six years old, the latter being the age of starting compulsory primary education, participate in preschool education activities. On average, $18 \%$ of Roma aged from 6 to 24 years old attend a school level below that corresponding to their age. The percentage of early school leaving among the Roma is disproportionately high compared to the general population. Segregation at school continues to be a problem in Bulgaria, Greece, Hungary and Slovakia.

Moreover, and notwithstanding the profusion of social and educational policies and the implementation of National Strategies (and European) aimed at integration of Cigano communities (2013-2020), among the Ciganos and compared to the rest of the Portuguese population, there continues to be low schooling levels, high rates of educational underachievement, dropout and illiteracy, as well as low rates of higher education graduates.

Despite the constraints imposed on the production of ethnic-based statistics in Portugal, nevertheless, some surveys and research projects have been conducted enabling us to get a closer and quantified look at the presence of Ciganos in Portuguese schools. The most recent data relative to the academic year of 2016/ 2017 (DGEEC 2018) are very revealing. Out of a total of 10,349 Cigano students enrolled, $48 \%$ had been held back to repeat the year in one or more years, denoting a direct relationship between the rate of repeating the year and the schooling level. In other words, this rate decreases as the schooling levels rise, being $45.4 \%$ for students of the first cycle of Elementary Education; shifting to $23.7 \%$ in the second cycle of Elementary Education; $13.8 \%$ in the third cycle; and $2.0 \%$ in Secondary Education. ${ }^{3}$

Although the overall school dropout levels stand around $5.9 \%$, it is important to highlight some nuances which should not be ignored and are interesting to scrutinise, as this figure reaches $11.3 \%$ in the second cycle of Elementary Education and $8.8 \%$ in the third cycle. Gender inequalities are particularly marked, namely in the Lisbon metropolitan area, where the dropout rate of girls in secondary education is $37.5 \%$ (compared to $16.2 \%$ among boys); $25.1 \%$ in the second cycle of Elementary

\footnotetext{
${ }^{3}$ The age of entry per elementary cycle in first cycle: 6 to 9 years old, second cycle 10 to 11 years old, and third cycle 12 to 14 years old; and in secondary: 15-18 years. Compulsory education is 12 years.
} 
Education (versus 8.2\%) and $20.4 \%$ in the first cycle of Elementary Education (versus 14\%).

In this scenario, it is also noteworthy that there is a growing interest of Cigano families in Home Schooling, with highest participation seen among girls, primarily in the second cycle (52 versus 12 boys). Alongside this, Distance Learning appears to be yet another resource that families have mobilised. On a purely illustrative note, 5 Cigana girls aged between 10 and 13 years old were identified as attending Distance Learning (Oliveira 2018), resident in an area assigned to a small socioeducational intervention project in a neighbourhood in the city of Lisbon. However, the real impacts and outcomes of these two educational offers among Cigano children and youth are as yet unknown. Although the families consider this type of schooling positive, in practice, the young people feel a lack of support and it remains to be ascertained whether this does not consist of yet another new way of segregating young Ciganos (Mendes et al. 2020), separating them from real school contexts and from intercultural and interethnic conviviality.

These data complement the available information that was collected under the National Study on Cigano Communities (Mendes et al. 2014), which surveyed 1599 Cigano individuals on national territory. This study reveals that $1 / 3$ of the respondents never attended school or did not go beyond the first cycle of Elementary Education; only $2.8 \%$ possessed a secondary school and/or higher education diploma (Mendes et al. 2014). In contrast, in the same year, $19.2 \%$ of the Portuguese population had completed secondary education and $16.5 \%$ higher education (Pordata 2014). However, these schooling levels are not distributed homogenously and uniformly throughout the country, as patterns of regional nature stand out clearly, with illiteracy rates being higher in the Algarve and Alentejo, standing at 39\% and 38\%, respectively. It is in the North and Lisboa e Vale do Tejo regions that these rates are lowest. Conversely, it is in these regions and in the Centre that a higher proportion of people with at least the third cycle of Elementary Education is concentrated.

\section{Methods and Fieldwork}

The methodology adopted in this study is qualitative and combines several techniques: documentary analysis, institutional interviews and interviews to Ciganos in order to collect information about numerous experiences and life paths regarding the impact of the social policy measures, mainly in the area of education. Taking this into account and aiming to cover and analyse the main impacts of public policies in education, we adopted several strategic methods: (1) mapping and characterisation of the institutions, services and ongoing social intervention projects in the Lisbon and Porto metropolitan areas; and (2) we conducted 36 interviews 18 in each of the territories addressed, such as within Private Welfare Institutions, Local Authorities, Groups of Schools, Local Development Associations and other NGOs. As a result of the interviews to socio-institutional actors (NGOs, public services, churches, 
mediators, Cigano representatives) that we have always considered as key interlocutors due to their intervention experience, knowledge and territorial proximity, we were able to map and characterise, on a preliminary basis, the Cigano population and its living conditions. We investigated whether the Ciganos live in well-identified communities or in big groups or in small groups or even isolated in areas mainly inhabited by the non-Cigano population (Rughiniş 2010, pp. 360-361), the constraints and opportunities of integration and some of its basic features.

It is estimated that the Cigano population covered by the local projects, in which technicians and coordinators were interviewed, is approximately 1500 persons in the Porto Metropolitan Area and 6200 in the Lisbon Metropolitan Area. The role of the institutions in solving the problems of the Cigano population is especially mediation-namely in the connection, facilitation and streamlining of the access to different services-health, education, housing, social security, among others, most of the time helping to read the officially published information.

In a third moment, (3) 72 semi-structured interviews were conducted to Ciganos, 36 interviews in each area, in six selected territories where Ciganos live and there are ongoing local intervention projects. These interviews were conducted to 52 women and to 34 men in 3 neighbourhoods of the Lisbon Metropolitan Area and 3 in the Porto Metropolitan Area. The selection of these places was based on several factors: the ease of approach to the field due to the fact of having previous knowledge and contacts in the field; the presence of public policies and diversified measures; the presence of a significant number of Cigano individuals and families; the existence of projects in the territory (e.g. 'Escolhas' programme); the choice of diversified residence areas, type of housing, environment and location and the reference of these territories in the media news. The script of these semi-structured interviews focused on issues regarding school trajectories, taking into account gender issues, relationship between school and families, support and incentives for education, importance of the projects and social policy measures related to permanence, return, success and continuity of the Ciganos in school. The interviews were tape-recorded with the data subsequently being transcribed. The interview data were analysed using methods based on grounded theory (Strauss \& Corbin 1990) in which themes were coded and indexed, using MAXQDA software.

\section{Public Policies and Cigano Education}

Public policy measures are universal, so there are no specific measures in accordance with the social and cultural origins of individual citizens. The right to education, enshrined in the Constitution of the Portuguese Republic, and fair and effective equality in school access and success (articles 73-77) is of utmost importance in Portuguese society. In this context, the Framework Law of the Education System 
(Assembleia da República. 1986) established the general framework of the current educational system and defends universal, compulsory and free primary education. Since 2009, compulsory schooling has expanded to 12 years and it was established the universality of preschool education for children from the age of 5 .

In terms of educational support measures, we highlight, in particular, the Educational Territories of Priority Intervention Programmes (TEIP) and other alternative measures to regular education, such as the Integrated Education and Training Programme (PIEF), created in 1996 and 1999, respectively. Currently, TEIP3 is in force, under the auspices of the Ministry for Education and Science, which is guided by the central objectives of promotion of educational success, combat of indiscipline, early school leaving and absenteeism, educational guidance and qualified transition from school to active life, and coordination between school, family and community. Under the joint supervision of the Ministry for Solidarity, Employment and Social Security, PIEF is an exceptional measure aimed at encouraging compliance with compulsory schooling by minors and ensuring the academic and professional qualification of minors aged 16 years or over, in a situation of exploitation of child labour, namely, those that have concluded employment contracts.

The 'Escolhas' programme also deserves attention, having appeared in its first generation in 2001, and is now in its sixth generation (2016-2018). The main objective of this programme is to promote the social inclusion of children and youths from the most vulnerable socioeconomic contexts, with a view to equal opportunities and the strengthening of social cohesion. This measure includes the most important actions developed in promoting school inclusion and non-formal education, due to its impact on Cigano youngsters and families (Calado 2014, p. 73).

In terms of housing, the State has financially invested in distinct actions of relocation in social housing with controlled costs (built or acquired), especially the Special Relocation Programme (PER), which began in 1993. Under this public housing policy many Cigano families have been rehoused all over the country, almost always in a concentrated form, with superficial knowledge about their ways of life and without taking into account certain particularities (Pereira and Rebelo 2013).

Another important area of public policies involves the social protection of citizens. In this respect, it should be noted that the guaranteed minimum income (RMG) was created in 1996, applied from 1997 onwards, and replaced in 2003 by the social integration income (RSI). These social policy measures to fight poverty are intended to support people or families who find themselves in a situation of serious economic distress and at risk of social exclusion. In these cases, the State provides a cash benefit to meet basic needs, and an insertion programme that encourages social, professional and community integration. Although there is no available data at a national level on the number of Cigano beneficiaries, those that are available do not precisely unveil this situation (Branco 2003). In 2008, the Social Security Institution disclosed that $3.9 \%$ of Cigano families were beneficiaries (5275 out of 42,8131) (Parliamentary Committee 2008); other sources attest that 35.9\% of Ciganos of active age received social integration income (Santos et al. 2009). Recently, the national study on Cigano communities reveals that among 6089 Ciganos (who are 
the head of households) the main income source of $33.5 \%$ is social integration income (Mendes et al. 2014, p. 185).

The Promotion of Education Operational Programme (OPRE) has been enforced since 2016, arising from a partnership between the Portuguese High Commission for Migration (ACM), through the 'Escolhas' programme, and a Cigano association ('Associação Letras Nómadas' or Nomadic Letters Association). This initiative is directed at students of Cigano origin that are attending higher education, and aims to attenuate the existing barriers between Ciganos and the formal education system as well as to prevent early school leaving in this study cycle. However, the selection criteria and the impact of the program are not known until now. It is important to mention that National Strategy for the Integration of Cigana Communities was reviewed in 2018, being perceived as an integrated and intersectorial approach, aligned with other national strategies such as the National Strategy for Equality and Non-Discrimination 2018-2030 'Portugal + Igual', namely in the recognition of the particularity of Cigano people and their experiences of discrimination, as well as international commitments with the 2030 Agenda for Sustainable Development.

\section{Individuals, Families and Social Policies: The Voices from the Field}

In the two metropolitan areas the participation of Ciganos in the services and projects is generally high and the opinions expressed are mainly positive; these are strongly influenced by the creation and consolidation of relationships of trust with the technicians of welfare benefits and services, in general, and the institutions and technical managers of social integration income, in particular, in the case of Ciganos, play a central role in the available range of social protection. Although this is the primary benefit referred to in relation to Ciganos, social security support to motherhood, child allowance, supplementary child allowance in the case of disabilities and also some pensions were also mentioned. In turn, the receipt of unemployment benefit is barely mentioned for this population: cases of workers who have paid social security contributions are rare, whether on the part of self-employed workers or employees. One of the implications of the contracting inherent to the insertion plan signed for the receipt of social integration income is the need for registration at public employment centres, which leads to a high number of Ciganos having the formal status of unemployed (Marçano 2011).

Currently, in both metropolitan areas most Cigano families live in public housing with a residual number in leased houses of the private market or that have purchased a house. To address the processes of relocation under the Special Relocation Programme, the respondents were given the opportunity to express their disagreement concerning practices of concentration and segregation of Ciganos: in the same blocks and in the worst places of quarters (without exits, or without access to shopping facilities or transport, for example). 
In general, Ciganos that the respondents know are characterised by low schooling levels and high absenteeism and dropout rates, in the first and second cycle of primary education, respectively, but, currently, almost all children are integrated in the first cycle. The main explanatory causes of school leaving identified pointed to the centrality of Cigano marriage (Mendes 2007; Magano 2010; Nicolau 2010). Cigano families make a considerable investment in preparing their children, and in particular their daughters, for matrimonial union, very often devaluing their formal education. Girls begin to help their mothers in carrying out household chores from a very early age, constituting an important support, and learning housekeeping duties and how to take care of younger siblings, thus preparing for their future functions as mothers and housekeepers, after marriage.

I was the eldest, I took care of them all. (...) I was the one who did everything. My mother did the selling, went to the fairs and I was the one who did it. I tidied up, cooked, took care of my siblings. I was the eldest, I had to do everything. (woman, 40 years old, does not know how to read or write, has been a widow for 6 years of a Cigano marriage that occurred when she was 17 years old)

But I did everything like my mother at home. Little Cigana girl. . My father was in prison, my mother used to go and visit. My mother would go (I was 10 years old) and I would cook the meals, I would wash, I would wash my siblings. My mother would arrive and I would have done the meal. I was 10 years old; I already did everything (woman, 38 years old, $9^{\text {th }}$ year of the New Opportunities Programme, first Cigano marriage at 16 years old)

This last respondent recalls the beginning of her school pathway as follows:

Interviewer: What age were you when you first went to school?

Respondent: I was 12 years old.

Interviewer: When you first went?

Respondent: Yes, it was me who wanted to go. I grabbed my identity card and went to school.

Interviewer: When you were little, you never went to school?

Respondent: No, I never went.

Interviewer: Why?

Respondent: I don't know. One day I saw children coming out of a school. In those days they left at $1 \mathrm{pm}$. And I said to myself: "Ah, school". I thought that school was very important. My mother doesn't hear very well, she has hearing problems. I grabbed my identity card and said to my mother: "I am going to enrol at school, I want to go to school", and my mother: "Well, fancy that!". And I went and she is still employed there: "Look, I want to go to school", "You really do? Alright?". (woman, 38 years old, $9^{\text {th }}$ year of the New Opportunities Programme, first Cigano marriage at 16 years old)

In turn, the bibliography in the area of Ciganos/Roma and education focuses on poor outcomes and the consequent educational failure arising from primary socialisation, insufficient cognitive stimulation, meager language resources, lack of motivation for learning, the absence of expectations regarding school—often reinforced by the unawareness of Ciganos who have effectively completed the ninth and twelfth grade (low number of cases identified in the two metropolitan areas) or even enrolled in higher education (in the Lisbon Metropolitan Area for example, the known cases of Ciganos who have attended or are attending university are children of a non-Cigano father or mother). 
In what concerns the relations that Ciganos establish with school, we find gender inequalities, which, according to the respondents, is due to the roles traditionally assigned to Cigano women. The girls, in general, leave school earlier than boys (Mendes 2007; Magano 2010; Nicolau 2010).

The testimony of a teacher who participated in one of the focus group discussions is presented below, highlighting the need to provide technical and individualised support to Cigano students.

They need very individual and technical support for every one of them and someone with time. . so that we have time to be... I think that they gain a lot from relations of trust which are able to be established and without time and without resources that's not possible. [...] They have difficulties in learning... Therefore, they need a person practically for each one. A ratio of one to one, at the moment, is very, very difficult, it's impossible! (Teacher, $2^{\text {nd }}$ and $3^{\text {rd }}$ cycles)

In contrast, on the part of some families who also participated in the focus group discussions, there is clearly an attitude of acceptance of school dropout as "natural"

I have a fifteen year-old daughter. My daughter is married. She married at the age of fifteen. She liked the man, she went. I did not go and take my daughter away from the man. I did not go racing after her, I did not order my daughter to marry. She liked that man, she went, she's married to a man, she's fifteen, and now I am going there to take her away? Now the Court is going to arrive and take my little girl from the man? That would be the last straw! (Cigano woman, does not know how to read or write, social insertion income beneficiary).

Thus, the strong pressure exerted on girls and on their families determines that the "need" to drop out of school at puberty, instilled and announced from a tender age, is internalised by these young people who also accept it as natural.

Interviewer: At what age did you leave?

Respondent: Around 14 or 15 years old.

Interviewer: And why did you leave?

Respondent: Because I was already feeling grown-up, I no longer felt comfortable at school. So there. There was also no-one left of my ethnicity and it was that thing of not having anyone. So, I left school. (woman, 22 years old, married, dropped out of school in the $7^{\text {th }}$ year and later completed the $9^{\text {th }}$ year in a vocational course)

For a large number of the interviewed representatives of institutions, the disadvantaged situation that marks the Cigano/school relationship is due to the lack of positive aspirations and expectations towards school. Usually, the social factors associated with ethnicity underlie the arguments for this type of explanation, the tradition and the need to preserve Cigano values. In fact, concerns about the preservation of cultural and family values are well-founded fears (Gwynedd \& McCluskey 2008).

The UNDP/World Bank/EC Regional Roma Survey (2011 and 2017) also shows significant differences in aspirations between Roma and non-Roma. One should however not conclude that differences are mainly caused by culture (Brüggemann 2012, p. 50).

However, some signs of changes in attitude and behaviour regarding gender relations in the analysed territories are visible, albeit gradually. Such learning opportunities over life (Gomes 2013) are often stimulated by the RSI teams and 
are very important for improving the living conditions of the Ciganos, and in particular of Cigano women, as education, training and qualification may enable integration into the labour market and social mobility, and may boost abandonment of the traditional way of life (Magano 2010).

The respondents even point out the relationship between the parent's appreciation of school and the tendency of their children's academic success, while confirming that the parents continue to hold low expectations as to the school's influence on the employability of Ciganos. It is also important to add that closed schools in poor and spatially segregated neighbourhoods normally present poor results. Moreover, the discontinuity in terms of projects and local intervention measures end up producing and reinforcing structural social inequalities.

Strangely, some of the professionals reproduce stereotypes traditionally associated with Ciganos, often homogenising and essentialising, almost always linking the perspective of poverty with social exclusion (Bastos et al. 2007; Magano 2010; Mendes 2012).

There are some areas where the path taken shows positive signs, such as in health, housing or education, even if only in the first cycles of primary education. However, these negatively emphasise the core issues of employment and more transversely of prejudice, preventing the Ciganos' integration and full participation in many spheres of social life; as well as the reinforcement of focus on education and training courses for the second cycle of primary education; the creation of school models and expectations adjusted to Cigano children and youngsters, for example through knowledge of reference Cigano youngsters and adults integrated in schools or in the labour market; the implementation of measures for protected employment; the appreciation of Cigano history and culture by promoting activities aimed at society in general. The respondents showed lack of knowledge about some social policy measures in spite of working in institutions deployed in the field. For example, although they have already heard about the national strategy for the integration of Cigano communities, they are unaware of its content and specific strategies, i.e. there is not a thorough understanding of the document and targets.

\section{Portuguese Ciganos: Social Changes and Continuities Towards School}

Some generational changes were observed in what concerns valuing school, breaking with the past. These changes are related to the fact that many parents with children attending classes are themselves educated and have engaged in greater follow-up of their children's educational background. The future of their children is perceived in a different light, putting in perspective the possibility of pursuing a career choice and considering the expectation of economic stability, social mobility through work, the value of school as the means to achieving a 'good job' and not as an end (better education). 
We went to school alone, there wasn't that business of going with their children, of meetings, it was different, I think that things have changed now (woman, 31 years old, $4^{\text {th }}$ year)

I would even cry, that I wanted to go to school, but at that time the parents wanted the opposite! Nowadays, children don't want to go to school, but we force them! And at that time, we wanted to go to school and our parents wouldn't let us. (...) And also at school, they really teased us. Even the teachers... because we were Ciganos they put us apart. (woman, 45 years old, $2^{\text {nd }}$ year)

Another interesting aspect is the fact that none of the interviewed Ciganos with more education (secondary school and university) attended only regular education. Even in cases of further school education, this is due largely to the influence of public policy of educational nature or social protection reflected in educational options that were professionally guided in the case of the male interviewed.

For example, among the Ciganos interviewed in the Porto Metropolitan Area, seven young people were identified whose school trajectories, already completed or not, involve secondary education, although with a single exception, all through professional routes, which also represents a progression compared to the previous generation.

Therefore, from the time they are twelve or thirteen years old, they [the girls] are promised or something else, they no longer come here. And as they move upwards, $2^{\text {nd }}$ cycle, $3^{\text {rd }}$ cycle, secondary, the funnel gets increasingly narrower, there are increasingly less students of Cigano ethnicity, and in secondary there will be two or three students here but more linked to vocational courses and not in regular education. In the $2^{\text {nd }}$ cycle there are some students that are in some so-called classes of regular education, in the $3^{\text {rd }}$ cycle they start to turn towards $\mathrm{CEFs}^{4}$ or, let's say, alternative pathways. (Teacher of the $1^{\text {st }}$ cycle, AMP)

Abajo and Carrasco (2004) point to other elements beyond institutional that are also relevant in explaining the school success of the Cigano population: the existence of personal continuity projects; individual undertaking and pursuit of favourable conditions for the implementation of such projects; the capacity to negotiate with family, community and pear pressure; social skills and support of pears.

Among the respondents there remains a tendency to value school as a way of achieving a different job that would allow them to have a better life than that of their parents. Continuity in school is seen as a way to access employment. Together, schooling and employment are seen as drivers of social mobility where the valorisation of school continuity and access to employment are directly linked.

Effective schooling is positively influenced by social support, whether through the importance of the support of school employees or local projects, individually and this, in a way, reveals how education is done: by a combination of several methods entailing regular education and alternative teaching proposals. Most of the time continuity occurred by stages as opportunities were found to arise, revealing the connections with public policies in which individuals and families are involved.

\footnotetext{
${ }^{4}$ The Education and Training Courses (CEF) represent an opportunity for youth aged 15 years old or more to complete compulsory schooling, through a flexible path adapted to their interests, enabling them to enter the world of employment in a qualified manner.
} 
For technicians and some teachers, the participation of Cigano families in school is still lower than that of non-Cigano families although increased interest is recorded: it is perceived that nowadays children go to school at appropriate ages and that the first cycle of primary education is a widespread reality. There is also increased attendance in nurseries, kindergartens and afterschool support for homework and studying.

The attendance of nurseries and kindergarten is viewed as preparation for upcoming schooling, playing a valuable role in facilitating entrance into elementary school.

Because they are progressively taught, they [the children] acquire other habits, they become more educated. They have rules for this and that. It's good. They socialise with other children. It's very good. Because just being at home is also bad for them. And like this they begin to socialise. They learn how to play... (woman, 43 years old, $4^{\text {th }}$ year of schooling

It's good, by the time they go to school they know how to write their name, they already know little things, the colours, they already know the colours. It's good. But my Patrício, he never liked going either. He went when he was very young, he was 2 years old. It was punishment to go. But he still went. It's good for learning. The teachers very often help, by the time they arrive at school they already know. With my granddaughter... She is at preschool and she already knows how to write her name, the colours. She knows how to say lots of things and she's only 4 years old. When she goes to school she will already know. (woman, 38 years old, $9^{\text {th }}$ year of schooling)

Another relevant aspect highlighted as a difficulty is the non-continuation of the teaching body which eliminates their preparation to work in these environments. Achieving outreach educational work is important and possible through convenience and mutual understanding. For that, it would be important for teachers to stay in school longer in order to enable getting to know the children and their families, and also to develop teaching materials and appropriate approaches.

Solutions found by schools with Cigano children and youngsters tend to concentrate Cigano students in the same classes of regular school (mostly in the first cycle of primary education) and in specific educational activities (e.g. alternative curricular paths). These classes have, as a general rule, worse results and greater teaching difficulties. Cigano students often get to second grade without the necessary skills to succeed in a new educational cycle of schooling.

Institutional players highlight the incapacity of schools to ensure that students do not miss school from the second cycle of primary education. In this second cycle of primary education there are some significant changes for children, youths and families: distant schools, increased number of teachers for different fields, i.e., teachers lose the importance shown in the first cycle of primary education. Subjects and learning contents became more complex and there is no advance preparation, difficulties tend to accumulate. To overcome the situation, work in partnerships between territory institutions is suggested.

On the other hand, in Cigano discourse there is a valuation of the skills gained in the first cycle of primary education, namely reading and writing, which are essential for reading functions and getting a driving licence. Some fears remain in what concerns school ('insecurity') and school environment, mostly in territories with a 
stronger history of conflict or with a strong presence of an immigrant population, but there is a very positive distinction regarding schools of first cycle of primary education.

The reasons for early school leaving are almost always related to the instilled centrality of marriage and preservation of women's 'purity'; it is difficult to accept the teaching of certain curricular contents (e.g. related to reproduction). We are still witnessing differentiation in what concerns support to continuity of school from parents, according to gender. Girls are not encouraged to continue school from a certain age (menarche) and year of schooling (variable). For the boys the situation is different, they have the possibility to decide, which constitutes an individual option for young men.

Generally, early marriage and childbirth disrupt schooling and continuity in school (Mendes 2005, 2012; Casa-Nova 2008; Nicolau 2010; Magano 2014) after which education takes place only through vocational/training courses in cases where they are beneficiaries of social protection and are compelled to take these courses.

Even in cases of schooling extension we notice some degree of disenchantment due to lack of opportunity that persists even with the increased schooling: even those with more schooling years have more difficulties of inclusion in the labour market and feel discriminated. It is almost always considered an effort of the students and their families which is not reflected in new opportunities.

There is almost always a positive image of the teachers. Nevertheless, concrete reports persist of situations of discrimination in some territories and schools concerning a few boards and teachers.

Families experience difficulties in supporting home schooling due to lack of knowledge required to enable this follow-up and also as a result of lack of space to study due to household size: the presence of many people at home and the noise implies that it is difficult to study.

As a way to lessen difficulties in learning and improve the relationship between school and families and that of the families with school, mediators could be an effective option. There are known cases of good performance of some school mediators and that presence is highly valued in attenuating some of the major recurring problems.

The idea that enjoying school does not always mean enjoying classes does not merit reservations. Youngsters like to hang out at school but are not very interested in classes. Parents do not feel responsible when their children skip school; this is seen as the school's responsibility. In contrast, the attendance of local projects is valued, like the project 'Escolhas', among others, which enable access to school support and recreational activities.

\section{Conclusion}

Nowadays, it is rarely the case that Cigano boys and girls are not integrated in the school system at the first cycle level. However, from here onwards difficulties continue to persist, with high school dropout levels. While this situation varies 
among different territories, an increasing number of Cigano youths, the more and the less "brilliant", manage to overcome this barrier and continue their school trajectory, just like the other non-Cigano students. In any event, considering the dramatic reality that we encountered throughout the fieldwork, particularly from the third cycle, we were amazed to find that the official school data are not clear in relation to the number of Cigano youths, under the age of 18, that are in a situation of absenteeism. In some cases, the "numbers" relative to dropout were almost zero, when, on a daily basis, we met young Cigano boys and girls of school age who were not integrated in any school of the ethnographic territories.

As we observed, in the different School Groups, the cases of some Cigano students, who are above all boys, that completed the third cycle or attend secondary education continue to be presented as "exceptional" cases, of particularly "brilliant" students, just as a decade ago. We did not observe in any of the territories a gradual continuity of the schooling paths of all the Cigano students, going much beyond the first or second cycle of elementary education. On the other hand, the great majority of Cigano students, particularly the girls, who achieve third cycle academic years do not do so through Regular Education, but rather via different alternative training solutions that the School Groups we visited have progressively created to specifically enable the continuity of the schooling of some Ciganos, notably the girls. We highlight, in particular, the case of the Alternative Curricular Paths (PCA) and the Integrated Education and Training Programme (PIEF), in this last case more targeted at Cigano girls, Training Offers that the people contacted in the field refer to as targeting Cigano students. These involve classes where the percentage of Cigano students reaches around $85 \%$. It is notable that, according to what was conveyed to us, School Groups cannot establish classes just with Cigano students without explicit authorisation from the Ministry of Education, and, as a rule, such requests have been systematically rejected.

Although the PCA and PIEF have enabled many young people, boys and girls, to extend their permanence at school and continuity of their schooling path for a few more academic years, allowing these students to complete the second cycle and many to attend and even complete the third cycle, particularly the boys and also increasingly the girls, we do not know what the later happens to these young boys and girls, and to what extent the training they received contributed to important changes in their lives, namely at a professional level. In fact, in the three territories, we found that the School Groups do not have any follow-up strategy for their male and female students, and do not have any way of assessing the real impacts of the work that has been developed. We found that more than guaranteeing professional integration, in general among Cigano students, the schools' greatest concern is to assure that the students remain within the school system (that they learn "basic rules") for as many years as possible, thus prolonging their schooling. On the other hand, the most "exceptional" cases, which continue to be almost exclusively male, considering the reality that we observed in the three School Groups, are currently provided with a diversity of Training Offers and Support Measures that have permitted the continuity of their schooling path and the acquisition of important skills for integration in the labour market, especially via vocational courses. In the 
three territories we felt that there was an excellent embracement of these students which are often used, for want of a better term, as examples for everything. As we observed, these students are proudly "exhibited" with a visibly enormous dedication, within their possibilities, by the School Groups in supporting these students. They are also frequently involved in school activities and presented as "success cases" in spheres outside the school.

It is also envisaged by many professionals contacted in the different territories that the fact of Cigano students, but especially the girls, staying in contact with school for a longer time, irrespective of the training offer in which they are placed, will always have impacts on their lives and, overall, on the integration of this population in the school system.

The impacts of schooling on professional life are still seen by Ciganos as not as significant as the expectations raised, which can be due to racism and discrimination issues. They are still very below the training average, despite being significantly higher than that of their parents, but they are always highly constrained in the labour market and when they access it, they almost always get the most disqualified jobs. In fact, the universalism of Portugal's public policies has not had the desired effects in terms of reducing the levels of poverty, exclusion, discrimination and racism concerning Ciganos.

Although the changes underway are quite marked with a greater presence of Cigano children and youths in public schools, there are still significant differences between the organisational and operating logics of the school institution and those of Cigano families, hindering the communication between these two relational spheres. In the first place, school teaching procedures appear to continue to be discordant with those activated within the family group, in which learning based on real experiences is favoured; in other words, acquired and incorporated know-how are simultaneously know-how-to-be and know-how-to-do. ${ }^{5}$ As stated by Jean Pierre Liégeois (1987, p. 63), the teaching procedures "unfold in the context of real tasks, through participation, and not through verbal instruction, and as preparation for future participation." Secondly, teaching contents are also of a very distinct nature, where the same author stresses that for Ciganos, the problems are essentially those of their daily life, "those of personal interaction, logical-formal generalisations are unknown, useless and replaced by specific and particular symbolisms, which reflect shared and reciprocal experiences." (Idem).

Thirdly, Cigano intergroup organisation and functioning logic continues to be distant from the way that the school institution is structured. Their lifestyle is still to a large extent based on the present, the immediate, on survival and management of daily life, with higher value given to outcomes than processes. Having a certain schooling level is not yet very important for the ethic and relational status and capital of the individual within her/his ingroup. For Ciganos, it is still above all the family's prerogative to ensure education, and not the school's mission. Non-Ciganos have a

\footnotetext{
${ }^{5}$ Liégeóis (1987, p. 216) also adds that "apart from the child's experience, none of the significances within the school are, for this child, of any significance."
} 
stereotyped representation of education which is portrayed by Cigano parents, considering it markedly permissive, sloppy, sometimes even negligent in which there are no prohibitions, rules, physical punishment and control, a representation disseminated in various European countries (Lukší 2019). However, the reality is far beyond what is apparent and, in fact, these children are prepared from a very early age, in a collective process and with a strong emotional charge, to be autonomous and independent, as well as respectful of the baseline and structuring values of the Cigano group. The socialisation of these children is markedly intergenerational and normally occurs in the context of the extended family, but in an informal manner, non-bureaucratised, experiential, by observation, imitation, mimicry; through the cohabitation and conviviality of various generations and in a collectively form, in which times, roles and tasks intermingle, not in a restrained way but rather contextualised in a polychronic cultural logic (Hall 1976).

Acknowledgements This research was supported by Fundação para a Ciência e Tecnologia, Portugal (Funding Agency for Science, Research and Technology) and by University Institute of Lisbon, Centre for Research and Studies in Sociology. The translation/revision of this text was provided by the Fundação para a Ciência e a Tecnologia through the Strategic Financing of the R\&D Unit UID/SOC/03126/2019.

\section{References}

Abajo, J. E., \& Carrasco, S. (Eds.). (2004). Experiencias y trayectorias de éxito escolar de gitanas y gitanos en España. Encrucijadas sobre educación, género y cambio cultural. Madrid: Instituto de la Mujer (MTAS) e CIDE (MEC), Colección Mujeres en la Educación.

ACIDI. (2013). Estratégia nacional para a Integração das Comunidades Ciganas 2013-2020. Lisboa: Alto Comissariado para a Imigração e Diálogo Intercultural.

Afonso, A. I. (Ed.). (2012). Etnografias com ciganos: diferenciação e resistência cultural. Lisboa: Colibri.

Almeida, J. F., Costa, S. F., \& Machado, F. L. (1993). A recomposição sócio-profissional e os novos protagonismos. In A. Reis (Ed.), Portugal 20 Anos de Democracia (pp. 307-330). Lisboa: Ed. Círculo de Leitores.

Assembleia da República. (1986). Lei n. ${ }^{\circ} 46 / 86$ de 14 de outubro. Diário da República n. ${ }^{\circ}$ 237/ 1986, Série I de 1986-10-14. https://dre.pt/pesquisa/-/search/222418/details/normal

Bastos, J., Correia, A., \& Rodrigues, E. (2007). Sintrenses ciganos. Uma abordagem estrutural dinâmica. Lisboa: Câmara de Sintra/ACIDI.

Bereményi, A. B., \& Carrasco, S. (2015). Interrupted aspirations: Research and policy on Gitano education in a time of recession, in Spain. Intercultural Education, 26(2), 153-164.

Branco, F. (2003). Os ciganos e o RMG: Direitos sociais e direito à diferença. Intervenção Social, 27, 21-143.

Brüggemann, C. (2012). Roma education in comparative perspective. Analysis of the UNDP/World Bank/EC regional Roma Survey 2011 (Roma Inclusion Working Papers). Bratislava: United Nations Development Programme.

Calado, P. (2014). O papel da educação não-formal na inclusão social: a experiência do Programa Escolhas. Interacções., 10(29), 60-94.

Casa-nova, M. J. (2008). Etnografia e produção de conhecimento. Reflexões críticas a partir de uma investigação com Ciganos. Lisboa: ACIDI-Alto Comissariado para a Imigração e o Diálogo Intercultural. 
Conselho de Ministros, Resolução do Conselho de Ministros n..$^{\circ}$ 25/2013, (2013, 17 de abril)). Diário da República $1 .^{\mathrm{a}}$ série - N. ${ }^{\circ} 75$.

DGEEC. (2018). Perfil escolar da comunidade cigana 2016/17. Lisboa: DGEEC.

ERRC/Númena. (2007). Os Serviços Sociais ao Serviço da Inclusão Social. O Caso dos Ciganos. Lisbon and Budapeste: ERRC_-European Roma Rigths Centre, and Númena - Centro de Investigação em Ciências Sociais e Humanas.

EU Fundamental Rights Agency. (2016). Segundo Inquérito sobre Minorias e Discriminação na União Europeia Ciganos: resultados selecionados. Luxemburgo: Serviço das Publicações da União Europeia.

EU Fundamental Rights Agency. (2017). Fundamental Rights Report 2017. Retrived from http:// fra.europa.eu/en/publications-and-resources/publications/annual-reports/fundamental-rights2017\#roma

European Parliament. (2011). National Roma integration strategies. European Parliament Resolution (2010/2276 (INI)). Strasbourg: European Parliament.

European Union Agency for Fundamental Rights. (2012). The situation of Roma in 11 EU member states survey results at a glance. Luxembourg: Publications Office of the European Union. http://fra.europa.eu/sites/default/files/fra_uploads/2099-FRA-2012-Roma-at-a-glance_EN.pdf.

FRA. (2012). The situation of Roma in 11 EU member states survey results at a glance. Luxembourg: Publications Office of the European Union. https://fra.europa.eu/en/publication/2012/ situation-roma-11-eu-member-states-survey-results-glance.

Gatti, R., Karacsony, S., Anan, K., Ferrè, C., \& Nieves, C. D. P. (2016). Being fair, faring better Promoting equality of opportunity for marginalized Roma. Washington: World Bank. http:// www-wds.worldbank.org/external/default/WDSContentServer/WDSP/IB/2016/06/03/ 090224b08438f623/3_0/Rendered/PDF/Being0fair00fa0or0marginalized0Roma.pdf.

Gomes, M. C. (2013). Políticas públicas de qualificação de adultos e comunidades ciganas: movimentos inclusivos. In M. M. Mendes \& O. Magano (Eds.), Ciganos Portugueses: Olhares Plurais e Novos Desafios numa Sociedade em Transição (pp. 81-91). Mundos Sociais: Lisboa.

Gwynedd, L., \& McCluskey, G. (2008). Education and gypsies/Travellers: 'Contradictions and significant silences'. International Journal of Inclusive Education, 12(4), 331-345.

Hall, E. T. (1976). Beyond culture. Garden City: Anchor/Doubleday.

Instituto Per La Ricerca Sociale (IRS). (2008). The social situation of the Roma and their improved access to the labour market in the EU. Milan. http://www.europarl.europa.eu/document/activi ties/cont/201107/20110718ATT24290/20110718ATT24290EN.pdf

Liégeois, J.-P. (1987). Gypsies and travellers: Dossiers for the intercultural training of teachers: Socio-cultural data: Socio-political data. Strasbourg: Council for Cultural Co-operation.

Lukší, I. (2019). Children from marginalized Roma communities at the school gates: The disconnect between majority discourses and minority voices. Early Childhood Education Journal (Online), 47(6), 1-11.

Magano, O. (2010). Tracejar Vidas Normais. Estudo Qualitativo sobre a Integração Social de Indivíduos de Origem Cigana na Sociedade Portuguesa (Tese de doutoramento em Sociologia. Universidade Aberta).

Magano, O. (2014). Tracejar vidas 'normais. Estudo Qualitativo sobre a Integração dos ciganos em Portugal'. Lisboa: Editora Mundos Sociais.

Marçano, I. (2011). Estado e Cidadão: papel social do desempregado em Portugal. Sociologia, Revista da Associação Portuguesas de Sociologia, 2, 551-564.

Mendes, M. M. (2005). Nós, os Ciganos e os Outros: Etnicidade e Exclusão Social. Lisboa: Livros Horizonte.

Mendes, M. M. (2007). Representações Face à Discriminação. Ciganos e Imigrantes Russos e Ucranianos na Área Metropolitana de Lisboa (Tese de doutoramento em Ciências Sociais, Instituto de Ciências Sociais).

Mendes, M. M. (2012). Identidades, Racismo e Discriminação: ciganos da AML. Lisboa: Caleidoscópio. 
Mendes, M. M., \& Magano, O. (Eds.). (2013). Ciganos Portugueses: Olhares Plurais e Novos Desafios numa Sociedade em Transição. Lisboa: Editora Mundos Sociais.

Mendes, M. M., Magano, O., \& Candeias, P. (2014). Estudo Nacional sobre as Comunidades Ciganas. Lisboa: Edição Alto-Comissariado para as Migrações.

Mendes, M. M., Magano, O., \& Costa, A. R. (2020). Ciganos Portugueses: escola e mudança social. Sociologia Problemas e Praticas, 93, 109-126.

Nicolau, L. (2010). Ciganos e Não Ciganos em Trás-os-Montes: Investigação de um Impasse Interétnico (Tese de doutoramento em Ciências Sociais, Universidade de Trás-os-Montes e Alto Douro).

O'Hanlon, C. (2010). Whose education? The inclusion of gypsy/Travellers: Continuing culture and tradition through the right to choose educational opportunities to support their social and economic mobility. Compare, 40(2), 239-254.

Oliveira, V. (2018). Relatório de Estágio em Serviço Social. Lisboa: Universidade Lusófona de Humanidades e Tecnologias.

Parliamentary Committee on Ethnics, Society and Culture. (2008). Subcommittee for Equal Opportunities and Family. Relatório das audições efectuadas sobre Portugueses Ciganos no âmbito do Ano Europeu para o Diálogo Intercultural, Lisboa.

Pereira, Á., \& Rebelo, M. (2013). Habitação e integração social. Que desafios lançam os grupos étnicos minoritários? In M. M. Mendes \& O. Magano (Eds.), Ciganos Portugueses. Olhares plurais e novos desafios numa sociedade em transição (pp. 61-70). Editora Mundos Sociais: Lisboa.

PORDATA. (2014). Base de dados de Portugal Contemporâneo. https://www.pordata.pt/en/Home

Rughiniş, C. (2010). The forest behind the bar charts: Bridging quantitative and qualitative research on Roma/Țigani in contemporary Romania. Patterns of Prejudice, 44(4), 337-367.

Santos, T., Oliveira, C. R., Rosário, E., Kumar, R., \& Brigadeiro, E. (coord.). (2009). Research survey on migrant's experiences of racism and xenofobia in Portugal. Porto Salvo: Númena.

Seabra, T., Roldão, C., Mateus, S., \& Campos, A. (2016). Caminhos escolares de jovens africanos (PALOP) que acedem ao ensino superior. Lisboa: Observatório da Imigração/ACM.

Silva, M. C., Sobral, J. M., \& Ramos, M. (2008). Ciganos e não-ciganos: imagens conflituosas em contextos de vizinhança - o bairro social de Atouguia, Guimarães. VI Congresso Português de Sociologia-Mundos Sociais. http://www.aps.pt/vicongresso/pdfs/246.pdf

Strauss, A., \& Corbin, J. (1990). Basics of qualitative research. London: Sage.

UNDP/World and Bank/EC. (2011 and 2017). Regional Roma survey. http://www.eurasia.undp. org/content/rbec/en/home/library/roma/regional-roma-survey-2017-country-fact-sheets.html

UNESCO. (2010). Reaching the marginalized, EFA, Global Monitoring Report. Oxford University Press: UNESCO.

Vala, J., Brito, R., \& Lopes, D. (1999). Expressões do racismo em Portugal. Estudos e Investigação. Lisboa: ICS.

Open Access This chapter is licensed under the terms of the Creative Commons Attribution 4.0 International License (http://creativecommons.org/licenses/by/4.0/), which permits use, sharing, adaptation, distribution and reproduction in any medium or format, as long as you give appropriate credit to the original author(s) and the source, provide a link to the Creative Commons licence and indicate if changes were made.

The images or other third party material in this chapter are included in the chapter's Creative Commons licence, unless indicated otherwise in a credit line to the material. If material is not included in the chapter's Creative Commons licence and your intended use is not permitted by statutory regulation or exceeds the permitted use, you will need to obtain permission directly from the copyright holder.

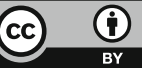

